tional power become meaningless at the saturation capacity; moreover the certainty of retaliatory destruction of even the largest states has profoundly modified any instrumental meaning of sovereignty.

In this situation the world now has a new kind of power vacuum-not the territorial vacuum of a weak state, but the functional vacuum resulting from inadequate means for maintaining what Niebuhr has called "the minimal community of the fate of the common threat of nuclear annihilation."

Herz' two concluding chapters present his "Plan for a Holding Operation," which explores almost all the recent proposals for at least minimal accommodation between East and West, and an analysis of "Universalism as Alternative to the Power Dilemma," which similarly surveys existing patterns on which stronger integrating developments toward a world polity might be based. In each he is careful to avoid utopianism, to trace out what seems possible when what seems desirable is clearly not to be.

The author has written a wise booka major contribution to the necesary reevaluation of political concepts in the contemporary world. He offers a refreshing contrast both to the pure power doctrinaires and to the pure utopians in international relations.

Professor of Government

Oliver Benson

University of Oklahoma

\section{AMERICAN HISTORY AND GOVERNMENT}

Robert E. Lane. Political Life: Why People Get Involved in Politics. Pp. 374. Glencoe, Ill.: Free Press, 1959. \$7.50.

What's in a name? When I entered Poland in May 1959 with Political Life in my baggage, the customs officials at the border promptly impounded it. Despite prolonged protest I did not get it back until I left the country two weeks later. I rather doubt that the Polish authorities would have found Professor Lane's book very dangerous if they had taken the trouble to read it. It is not a controversial volume. However, they would have found it a most extraordinary source of information about political life in the United States.

The field of inquiry dealing with what is known as political behavior is an interdisciplinary hybrid. Political science, sociology, and psychology share in its parentage; none of them can fully claim it. Its development in recent years has been characterized by tremendous vigor but very little organization. A great variety of studies have appeared in the literaturemass studies, community studies, legislative studies, case studies, even psychoanalytic studies-their direction seeming to come much more from the inspiration of their authors than from any central theme.

Professor Lane has undertaken to review this scattered profusion of empirical studies. Despite occasional omissions-the Robinson-Hayes studies of the 1932 election, for example-and a tendency to accept uncritically data of very various quality, his accomplishment is impressive. There is certainly no other place where one can find such a complete and detailed report of the published and unpublished material in this area of study.

However the book is far more than an encyclopedia of empirical facts. Taking participation as his basic variable, Professor Lane has attempted to synthesize the great disorder of data which have been accumulating over the years and to organize them around suggested hypotheses. The hypotheses he proposes are not always at a very high conceptual level and they are consequently not very systematically related to each other. One may regret this lack of elegance in Professor Lane's theoretical structure, but it reflects the level of sophistication at which empirical researchers in this field currently work. It is doubtful if a more generalized system of constructs could have been introduced without incurring a serious loss of contact with the available research data.

Professor Lane has carried out an ambitious work and one which needed very badly to be done. He has produced a document which will have undoubted value as a reference book for students of politi- 
cal behavior. It is not unrealistic to hope that it will also give stimulus and direction to future research developments in this field.

Angus Campbell

Director, Survey Research Center

University of Michigan

WIIFRED E. Binkley. The Man in the

White House: His Powers and Duties.

Pp. 310. Baltimore: Johns Hopkins

Press, 1958. \$6.00.

The title of this little volume is a bit misleading. The book is not about the man currently occupying the White House. Nor, for that matter, is it solely about the office or even the institution. This is not to suggest that an alternative title comes quickly to mind for the simple reason that the book is a miscellaneous collection of essays about some of the men who have held the office, about the techniques by which some of them were nominated and by which some of them were elected to the office, and about both the office and the institution.

In addition to various chapters dealing with the president as chief executive there are others on the president as party leader, chief legislator, commander-in-chief, chief diplomat, and so forth. There is even one interesting essay on the president as a national symbol and another on the vice presidency and succession to the presidency. The arrangement of the collection is somewhat strange in spots. A chapter on pressures on the president is not surprising but it is a little strange to find this chapter in between one on apprenticeship for the presidency and one on nominating methods. The pressures on the president would seem to come after he gets nominated and elected.

There is much in this collection about the office and about how the office has become completely institutionalized-so completely institutionalized in fact that even President Eisenhower had no choice but to accept and continue it.

The historical background material is particularly impressive. Professor Binkley knows his American history well. He has had a long and distinguished career as a teacher. Moreover, he has already written extensively and ably on party history, on Congress, and on the presidency itself. This volume is no exception. Like its predecessors it is lively, interesting, and informative. Laymen as well as professional students will find it exceptionally readable and tremendously worth while.

\section{E. Allen Helms}

Professor of Political Science

The Ohio State University

James Burnham. Congress and the American Tradition. Pp. $\mathrm{x}, 363$. Chicago: Henry Regnery Company, 1959. $\$ 6.50$.

Once more the provocative author of The Managerial Revolution and The Machiavellians has produced a challenging book on the perennial problem of maintaining a serviceable government in a modern state. Following his earlier excursions among the Communist and Fascist writers, he now has discovered the Founding Fathers and conducts an interesting exploration in the classic political literature and current political practices of his own country. What he finds causes him to view with alarm the present condition and prospects of the Congress of the United States. Congress, he fears, "is on its way out." The result, he concludes, will be fatal to traditional American liberty.

The evidence with which Mr. Burnham supports this thesis is carefully selected but unconvincing. Consider, for example, his treatment of the investigatory power of the Congress, which he regards as one of its most important attributes, and of the censuring of Senator Joseph R. McCarthy by the Senate, which he regards as a most deplorable sign of the deterioration of the American constitutional system. To the ordinary American citizen, who notes that Senator McCarthy was not censured for his gross abuse of the Senate's investigatorial prerogatives, or for his subversive attack against the executive branch of the government, or for his mistreatment of anyone other than his fellow-senators, the action taken against McCarthy seems to have been the least the Senate could have done to maintain its proper position in the constitutional system. But the Senate did maintain its own self-respect. 